\title{
A cultural exploration of consumers' interactions and relationships with celebrities
}

\author{
Emma N. Banister, Manchester Business School, UK \\ Hayley L. Cocker, Lancaster University Management School, $U K^{1}$
}

Emma N. Banister is a senior lecturer in consumer research at Manchester Business School. Her research is mainly focused around issues of identity and consumption. Key current projects relate to young adults' alcohol consumption and new mothers' identity transitions. Her research has been published in Advances in Consumer Research, Journal of Marketing Management, European Journal of Marketing, Journal of Business Research and Sociology of Health and Illness.

Corresponding author: Dr. Emma Banister, MOMS Division, Manchester Business School, The University of Manchester, Booth Street West, Manchester, M15 6PB

$\mathbf{T} \quad+44(0) 1612756327$

E_emma.banister@mbs.ac.uk

Hayley Cocker is a doctoral candidate in marketing at Lancaster University. Following an MSc in Advanced Marketing Management at Lancaster University Hayley worked as a research associate for a research agency specialising in customer behaviour. Her $\mathrm{PhD}$ explores young people's alcohol consumption and identity issues and is funded by the Economic and Social Research Council (ESRC).

T $\quad 01524510982$

E h.cocker1@lancaster.ac.uk

\footnotetext{
${ }^{1}$ Authorship is alphabetical, both authors contributed equally to this paper. We would like to thank Dr Maria Piacentini and Professor Margaret Hogg for reading and commenting on an earlier version of this paper. We would also like to thank the editor, associate editor and three anonymous reviewers for their very helpful and constructive comments and suggestions.
} 


\title{
A cultural exploration of consumers' interactions and relationships with celebrities
}

\begin{abstract}
This paper offers a cultural exploration of young adult consumers' everyday interactions and relationships with celebrities. Adopting an interpretive methodology, we build on McCracken's (1986; 1989) important work on cultural-meaning transfer, and integrate a contemporary understanding of consumers as co-creators of meaning, in order to explore their everyday experiences with celebrities. Findings suggest that consumers purposefully interact with celebrities in a diverse range of ways and actively engage in a variety of consumer-celebrity relationships. We conceptualise a range of consumer-celebrity relationship types and demonstrate the roles that celebrities can play in providing meaning and context to consumers' identity projects.
\end{abstract}

\section{Summary statement of contribution}

Our research builds on contemporary understandings of celebrity meaning transfer and in particular explores consumer-driven (rather than managerial) understandings of celebrity meanings. Our findings suggest that consumers' uses of celebrities are somewhat more active and purposeful than McCracken's (1989) model and much prior research suggests. Consumers develop portfolios of celebrity-relationships, or celebrityscapes (cf. Fournier, 1998), which allow consumers the freedom and opportunity to flit between different (often fragmented) identity positions.

Key words: celebrity; congruency; identity; possible selves; endorsement; interpretive method 


\section{A cultural exploration of consumers' interactions and relationships with celebrities}

\section{Introduction}

In the UK, interest in celebrities is reflected in magazine sales, television shows, internet searches and social media use. The notion of what constitutes a celebrity continues to expand. Hollywood stars and world-class athletes compete with glamour models and reality TV stars for attention. In contemporary consumer cultures, celebrities give consumers the possibility of knowingly and purposefully contributing to projects of the self (Arnould \& Thompson, 2005), via the provision of appropriate cultural types (O'Guinn, 1991). Yet consumer behaviour studies have tended to focus on celebrities' work in promotional roles (Erdogen, 1999) and not on consumers' active interactions with celebrities. These interactions can include playing with, and reworking, celebrity images, rather than a passive acceptance of those meanings with which celebrities, products and brands are imbued (Hamilton \& Hewer, 2010; Ritson \& Elliott, 1999).

Our research builds on contemporary understandings of celebrity meaning transfer and offers a cultural exploration of consumers' use of celebrity meanings in everyday consumption experiences, from the perspective of the consumer (Hamilton \& Hewer, 2010; Turner, 2010). We respond to McCracken's (1989) call for research into how consumers 'use the meaning of the celebrity in the construction of self and world' (p. 319). Our findings suggest that consumers' uses of celebrities are somewhat more active and purposeful than McCracken's (1989) model suggests. Consumers develop portfolios of celebrity-relationships, or celebrityscapes (cf. Fournier, 1998), which allow consumers the freedom and opportunity to flit between different (often fragmented) identity positions, with celebrities providing meaning and context to these identity projects. We propose a consumer-celebrity relationship 
framework which identifies a range of relationship types and links these to consumers' identity projects (Arnould \& Thompson, 2005).

\section{Understandings of celebrity}

Academic definitions of celebrity are often imprecise. Evans and Hesmondhalgh (2005, p.1) describe celebrities as 'the few, known by the many' and Rindova, Pollock and Hayward, (2006) take their starting point from the audience or consumers' notions of what constitutes a celebrity: 'a property of the actor's relationship with an audience, rather than a characteristic of the actor him/her/itself' (2006, p. 51). More recently, Rojek (2001) identifies three types of celebrity status - ascribed, achieved or attributed. Ascribed celebrity results from lineage; achieved reflects accomplishment and attributed is status built on media coverage (rather than specific talent or accomplishments). The number of people who achieve attributed status, 'celebrated not for doing but for being' (Gamson, 1994, p. 1), is symptomatic of a new era of celebrity. In addition, advancements in technology have increased viewers' illusions of intimacy with the famous (Leets, de Becker, \& Giles, 1995), with social and mass media facilitating connections with figures beyond individuals' immediate circle (Caughey, 1994).

\section{Celebrity meaning transfer}

McCracken argues that meanings transfer to consumers via consumer goods (1986), with celebrity endorsers functioning as intermediaries (1989). Celebrities are positioned as marketing tools, valued for their 'interconnected set of meanings' which can be associated with products and then passed on to consumers (1989, p.313). This approach positions consumers as relatively passive recipients of celebrity meanings, representing a top-down (celebrity to consumer) model, and celebrities as carriers of meaning. The approach is 
outdated in a fragmented contemporary world where social and mass media affords the consumer more control to select between celebrities and meanings (O'Reilly, 2005). In this present study, rather than seeing the consumer as 'the last step in the meaning transfer process' (McCracken, 1989, p. 316), the point at which consumers engage with celebrities takes centre stage, reflecting calls for a more cultural approach (Hamilton \& Hewer, 2010; Turner, 2004). We afford consumers a more active role in the meaning transfer process, and reflect concerns of Ritson and Elliott (1999) whose participants derive considerable meaning from advertisements, without necessarily consuming the goods that they advertise, and O'Reilly (2005) who positions cultural brands (celebrities) as socially and not just managerially constructed.

\section{Consumer-celebrity relationships}

Previous research has examined consumer-celebrity relationships, and specifically their point of difference from traditional face-to-face relationships. Consumer-celebrity relationships have primarily been represented as fantastical in nature: In psychiatry Horton and Wohl (1956) describe such relationships as para-social interactions; from a psychological perspective Koenig and Lessan (1985) suggest the appropriateness of the term quasirelationships; and Caughey (1985), in an anthropological study, discusses imaginary social relationships. From a consumer behaviour perspective O'Guinn (1991) refers to the touching greatness phenomenon whereby fans aim to achieve closer relations with their chosen celebrity via consumption activities (e.g. the purchase of memorabilia). Leets et al. (1995) explore attempts and motivations to develop two-sided relationships, via fan letters. While these latter two studies focus on individuals' attempts to build relationships with celebrities, they do not fully address the socio-cultural setting in which celebrity consumption takes place (Arnould \& Thompson, 2005; Ritson \& Elliott, 1999). In addition, contemporary consumercelebrity relationships are impacted by the heightened (consumer-celebrity and consumer- 
consumer) interaction opportunities afforded by social media such as Twitter (Hamilton \& Hewer, 2010).

Prior research has explored consumers' use of celebrity meanings (McCracken, 1989). Pringle (2004) asserts that celebrities can represent 'an enhanced fantasy reflection' (p. 12) and provide consumers with information regarding consumption products and practices that allow them to 'make the best of their appearance' (p. 23). Carroll (2008, p. 6) suggests celebrities' potential as 'super consumers' with strong self-images that communicate clear meanings for advertisers, a 'kind of exemplary, inspirational figure to the consumer' (McCracken, 1989, p. 317). Consumers can use fantasy orientations to either be or be with a celebrity: "in "being" a celebrity, consumers vicariously experience lives more interesting, romantic and dangerous than their own' and 'in "being with" a celebrity, consumers can gain an increase in their own social status and can experience intimacy without the risk of rejection' (Zimmerman \& Ayoob, 2004, p. 2). Wohlfeil and Whelan (2012) provide an example of this potential intimacy in their introspective study of a fan relationship with the actor Jena Malone, whereby fantasised romantic encounters with the actor are used to make up for what the first author sees as an unsuccessful romantic life. Caughey (1985) focuses on one woman's fantasies involving actor Steven Segal. In 'Gina as Steven', Gina's dreams are purely fantasy orientated and focus on a male celebrity who lives a very different life to her, with little indication of romantic aspirations. Both these studies (Caughey, 1985; Wohlfeil \& Whelan, 2012) provide cultural interpretations of a single consumer's interactions and relationships with a particular celebrity. Although for these individuals, these consumercelebrity relationships represent everyday interactions (Wohlfeil \& Whelan, 2012), these are essentially examples of fandom, which centre on feelings of escapism and fantasy and do not explore the potential for more ordinary everyday consumer-celebrity relationships and their impact on consumers' identity projects. 
There is, therefore, an opportunity to explore more routine or mundane functions of consumer-celebrity relationships, from the perspective of consumers, using a cultural approach, which recognises the contemporary context and marketplace. Recent research in the area of branding provides a starting point. Thomson (2006) recognizes that celebrities possess brand-like properties, which enable them to 'create awareness and an image of their own in consumer minds' (Seno \& Lukas, 2007, p. 123). A brand-driven approach to understanding consumer-celebrity relationships, while running the risk of presenting consumers as passive entities, indicates the potential to draw on other work in the branding area. Fournier's (1998) framework for the study of consumer-brand relationships illustrates the active role brands can play as repositories of meaning in the construction of self and includes a typology of relationships ranging from best friendship to enslavement. Implicit in Fournier's (1998) consideration of consumer-brand relationships are the functions these

relationships provide for consumers, a concern that is also relevant for consumer-celebrity relationships. Pimentel and Reynolds (2004) recognize the potential significance of consumer-brand relationships in their conceptual model for consumer devotion in which they draw on the experiences of football fans, demonstrating how these two contexts (brands and celebrities) offer potential theoretical similarities. Taking these theoretical similarities a step further, consumer culture theorists have recently discussed the creation and meaning of celebrity brands using the Nigella (Lawson) brand (Hewer \& Brownlie, 2009; Brownlie \& Hewer, 2011) and the (Andy) Warhol brand (Kerrigan, Brownlie, Hewer \& Daza-LeTouze, 2011) as illustrative cases.

\section{Self and self-image congruency}

Our primary interest is in what consumers do with celebrity and the roles celebrityinteractions play in consumer identity construction. This focus links with work in the area of symbolic consumption, whereby potential associations between products/brands and 
consumers' identities have been explored (Solomon, 1983). Consumers are said to actively engage in meaning making using brands as cultural resources to construct or reinforce identity (Elliott \& Wattanasuwan, 1998; Holt, 2002).

In the celebrity endorsement realm, Kahle and Homer (1985) suggest successful campaigns featuring celebrities will achieve a good match up (in the minds of consumers) between celebrity and product image. Celebrities should also be like the target audience in order to encourage some kind of liking for the advertisement/brand which could necessitate multiple endorsers (Hsu \& McDonald, 2002), and individuals specifically seek out celebrities with which they share an affinity (Boon \& Lomore, 2001). Rubin et al. (1985, p. 175) suggest individuals will start up imaginary social interactions with those media stars they perceive as 'real and similar'. However, existing managerially focused studies do not explicitly explore links between consumers and celebrities beyond broad categories (e.g. age and gender) (Hsu \& McDonald, 2002), and therefore shed little light on the potential to forge consumercelebrity relationships based on similarity.

The concept of congruency encompasses various notions such as fit, similarity and consistency and is reflected in business practices such as brand extensions, co-branding and celebrity endorsement (Fleck \& Quester, 2007). Key to this present study is the assumption that the concept of congruency can extend beyond brands to include celebrities as human brands (Thomson, 2006). Grubb and Grathwohl (1967) suggest consumers enhance their identity through the purchase of a product or brand whose image matches and complements their identity. However, more recent understandings of identity consider the self to be a flexible project (e.g. Firat, 1992; Shankar, Elliott, \& Fitchett, 2009) whereby consumers work with the market to 'forge a coherent if diversified and often fragmented sense of self' (Arnould \& Thompson, 2005, p. 871). Celebrities can represent 'competing representations of who we can be' (Shankar et al., 2009, p. 76) and as such can represent forms of marketer- 
generated materials. Indeed, King (2003, p. 45) suggests that with their 'decentred subject', contemporary celebrities reflect postmodern selves, and consumers use celebrities as a 'testing board for their self-identities' (Rose \& Wood, 2005, p. 295). Concepts like possible selves (Markus \& Nurius, 1986) and the situational self (Schenk \& Holman, 1980) provide early means to understand the multiple identities that consumers negotiate in response to the range of symbols (human or otherwise) available in the marketplace. Brands or celebrities provide the props to reflect changing (situational) or emergent self-images (Schenk \& Holman, 1980). Negative marketplace images can also influence these identity projects (Lee, Fernandez, \& Hyman, 2009). For example the negative self (Sirgy, 1982) draws on notions of negative possible selves (Markus \& Nurius, 1986), undesired selves (Ogilvie, 1987) and avoidance selves (Banister \& Hogg, 2001) and suggests consumers avoid products and brands which evoke negative aspects of identity (Hogg \& Banister, 2001). Consideration of out-groups (Escalas \& Bettman, 2005) and dissociative reference groups (White \& Dahl, 2007) may also shed light on negative consumer-celebrity relationships. When integrated with the notion of self-congruency and the consideration of celebrities as human brands, this research stream suggests that consumers also avoid, or demonstrate active disregard for, celebrities who fit predefined negative notions of identity (Hogg, Banister, \& Stephenson, 2009). Larsen, Lawson, and Todd (2010) suggest an extended version of Grubb and Grathwohl (1967) could include 'all manner of possible selves that may come to exist in certain situations' (p. 676), rather than the 'essentialist' notion of the self inherent in the initial conceptualization. This framework could be adapted to provide a fit with contemporary notions of (fragmented) identity and an approach to understanding consumer-celebrity relationships and their role in consumers' lives.

\section{Research aim and approach}


The overall aim of this study is to explore consumer-driven understandings of celebrity meanings. We are guided by two objectives. Firstly, to develop a contemporary understanding of celebrity-meaning transfer focused on consumers' everyday experiences with celebrities. Secondly, we seek to conceptualise consumer-celebrity relationships and identify the potential roles celebrities can play in consumer identity projects.

\section{Research design}

We conducted interviews with eleven young adults. The participants range from those who experience intense feelings towards celebrities (Caughey, 1985) to those who experience less intense feelings but who keep informed about celebrities in the media spotlight, which Leets et al. (1995) suggest is common behaviour. We sought to include consumers who could demonstrate the relevance of celebrities in the everyday lives of ordinary young adult consumers, as well as those who form more intense relationships, in order to shed light on a fuller scope of consumer-celebrity relationships.

The eleven participants (six women, five men) were recruited via convenience and snowballing techniques, and were purposefully selected in order to allow for information rich cases (Patton, 2002) and the exploration of a number of themes related to the topic under study. All interviewees were aged between 18 and 24 (see figure 1), given that younger adults are influenced by celebrities (Pringle, 2004), and that celebrities continue to shape developing identities into young adulthood (Boon \& Lomore, 2001). Participants were either university students or recent graduates, owing to the need to recruit via existing contacts and networks of the authors. Data saturation was achieved within this sample and is illustrated by the recurrent support for our themes/consumer-celebrity relationships in our framework (figure 4). 
Interviews were unstructured to more fully capture the perspective of each participant. The interviews were conducted by the second author, whose age is similar to that of the participants, in a relaxed, friendly, conversational manner within a setting of the participant's choosing (e.g. home, office). Interviews varied in length, quality of material and detail, and lasted between 1.5 to 2 hours.

Figure 1: Table of Participants

\begin{tabular}{|c|c|c|c|c|c|}
\hline Participant & Age & Occupation & Interests/ Activities & $\begin{array}{l}\text { Positive celebrity } \\
\text { relationships }\end{array}$ & $\begin{array}{l}\text { Negative celebrity } \\
\text { relationships }\end{array}$ \\
\hline Chloe & 23 & $\begin{array}{l}\text { Postgraduate } \\
\text { student }\end{array}$ & $\begin{array}{l}\text { Greek student, loves } \\
\text { spending time outdoors }\end{array}$ & $\begin{array}{l}\text { Sheryl Crow, Tammy Lee, } \\
\text { Jennifer Aniston, Cameron } \\
\text { Diaz }\end{array}$ & $\begin{array}{l}\text { Victoria Beckham, Carrie } \\
\text { Bradshaw and The Sex and } \\
\text { The City characters }\end{array}$ \\
\hline Daniel & 24 & $\begin{array}{l}\text { Full time } \\
\text { employment/ } \\
\text { Entrepreneur }\end{array}$ & $\begin{array}{l}\text { Interested in fashion } \\
\text { (expensive designer } \\
\text { wear) and living an } \\
\text { extravagant lifestyle, } \\
\text { keen footballer and a } \\
\text { Manchester United FC } \\
\text { fan }\end{array}$ & $\begin{array}{l}\text { Christiano Ronaldo, Jay-Z, } \\
\text { David Beckham, Justin } \\
\text { Timberlake, Callum Best }\end{array}$ & $\begin{array}{l}\text { High profile footballer who } \\
\text { plays for his favourite team. }\end{array}$ \\
\hline Ethan & 20 & $\begin{array}{l}1^{\text {st }} \text { year } \\
\text { undergraduate } \\
\text { student }\end{array}$ & $\begin{array}{l}\text { Keen cyclist, competes } \\
\text { in many road cycling } \\
\text { events }\end{array}$ & $\begin{array}{l}\text { Will Smith, Mark Cavendish, } \\
\text { Frankie Boyle, Pixie Lott, Una } \\
\text { Healy, Katy Perry, Russell } \\
\text { Brand }\end{array}$ & $\begin{array}{l}\text { Jade Goody, Katie Price, } \\
\text { Christiano Ronaldo }\end{array}$ \\
\hline Grace & 19 & $\begin{array}{l}1^{\text {st }} \text { year } \\
\text { undergraduate } \\
\text { student }\end{array}$ & Photography society & $\begin{array}{l}\text { Beyonce, Kate Middleton, } \\
\text { Leonardo DiCaprio, Eric } \\
\text { Northman }\end{array}$ & Paris Hilton, Katie Price \\
\hline Oliver & 19 & $\begin{array}{l}1^{\text {st }} \text { year } \\
\text { undergraduate } \\
\text { student }\end{array}$ & $\begin{array}{l}\text { Member of a ska band, } \\
\text { Keen footballer, Arsenal } \\
\text { FC fan }\end{array}$ & $\begin{array}{l}\text { Chad Stokes, Yannis } \\
\text { Philippakis, Thierry Henry, } \\
\text { David Beckham }\end{array}$ & $\begin{array}{l}\text { Kerry Katona, Katie Price, } \\
\text { Jade Goody, Justin Bieber, } \\
\text { Ashley Cole }\end{array}$ \\
\hline Luke & 24 & $\begin{array}{l}\text { Postgraduate } \\
\text { student }\end{array}$ & $\begin{array}{l}\text { Interests in Business, } \\
\text { plays football for a local } \\
\text { team, Manchester } \\
\text { United FC fan }\end{array}$ & $\begin{array}{l}\text { Stephen Fry, Warren Buffet, } \\
\text { Hugh Jackman, Russell Crowe, } \\
\text { Jose Morinho, Paul Scholes, } \\
\text { Mario Balotelli, Rosie } \\
\text { Huntington-Whiteley }\end{array}$ & $\begin{array}{l}\text { Frankie Cocozza, Kerry } \\
\text { Katona, Katie Price, John } \\
\text { Terry }\end{array}$ \\
\hline Lyndsey & 20 & $\begin{array}{l}2^{\text {nd }} \text { year } \\
\text { undergraduate } \\
\text { student }\end{array}$ & $\begin{array}{l}\text { Interested in sports, } \\
\text { keeping fit and living a } \\
\text { healthy lifestyle }\end{array}$ & $\begin{array}{l}\text { Cheryl Cole, Kate Beckinsale, } \\
\text { Jessica Alba, Eva Longoria, } \\
\text { Rachel Bilson }\end{array}$ & $\begin{array}{l}\text { Pamela Anderson, Jessica } \\
\text { Simpson, Katie Price }\end{array}$ \\
\hline Nathan & 18 & $\begin{array}{l}1^{\text {st }} \text { year } \\
\text { undergraduate } \\
\text { student }\end{array}$ & $\begin{array}{l}\text { Presents an evening } \\
\text { radio show for } \\
\text { University radio }\end{array}$ & $\begin{array}{l}\text { Zane Lowe, Shaun White, } \\
\text { Ryan Dunn from Jackass, } \\
\text { Mario Balotelli, Beyonce }\end{array}$ & $\begin{array}{l}\text { Paris Hilton, Justin Bieber, } \\
\text { Chris Brown, Ronan Keating }\end{array}$ \\
\hline Shreya & 23 & $\begin{array}{l}\text { Postgraduate } \\
\text { student }\end{array}$ & $\begin{array}{l}\text { Indian student, lives a } \\
\text { lavish lifestyle, loves } \\
\text { premium branded } \\
\text { products }\end{array}$ & $\begin{array}{l}\text { Kim Cattrall, Preity Zinta, } \\
\text { Aishwarya Rai }\end{array}$ & N/A \\
\hline
\end{tabular}




\begin{tabular}{|l|l|l|l|l|l|}
\hline Summer & 18 & $\begin{array}{l}1^{\text {st }} \text { year } \\
\text { undergraduate } \\
\text { student }\end{array}$ & $\begin{array}{l}\text { Part-time tennis coach, } \\
\text { interested in sports, } \\
\text { fashion and music }\end{array}$ & $\begin{array}{l}\text { Gillian Zinser, Lauren Conrad, } \\
\text { Rihanna, Beyonce, Jay-Z, } \\
\text { Justin Bieber, Rafael Nadal, } \\
\text { Novak Djokovic }\end{array}$ & Katie Price, Jodie Marsh \\
\hline Zara & 19 & $\begin{array}{l}1^{\text {st }} \text { year } \\
\text { undergraduate } \\
\text { student }\end{array}$ & $\begin{array}{l}\text { Spent her gap-year } \\
\text { working an internship at } \\
\text { a Magazine in Shanghai, } \\
\text { Member of Dance } \\
\text { society }\end{array}$ & $\begin{array}{l}\text { Nicole Scherzinger, Emma } \\
\text { Watson, Miranda Kerr, Kate } \\
\text { Middleton, Blake Lively, } \\
\text { Rafael Nadal, Lewis Hamilton, } \\
\text { Orlando Bloom }\end{array}$ & $\begin{array}{l}\text { Cheryl Cole, Taylor Momsen, } \\
\text { Lady Gaga }\end{array}$ \\
\hline
\end{tabular}

Prior to the interview, participants were asked to produce a collage which incorporated internet downloaded images that best described their style, the products and brands they purchase as well as the celebrities that influence their decisions, both positively and negatively (for examples see figures 2 and 3). Ideally we would have explored participants' worlds, and multiple selves, in a range of consumption contexts (as advised by Newholm \& Hopkinson, 2009), but the collages allowed participants the opportunity to bring a range of contexts (and celebrities) to the fore, rather than feeling restricted by themes introduced by the interviewer. We used the collages as an ice-breaker; they provided useful prompts throughout the interview in order to encourage participants to tell stories behind their selected images, in keeping with other studies that encourage some self-interpretation of projective materials (Banister \& Hogg, 2001; Belk, Ger, \& Askegaard, 1997; 2003, Chaplin \& John, 2005).

\section{Figure 2: Collage example 1}




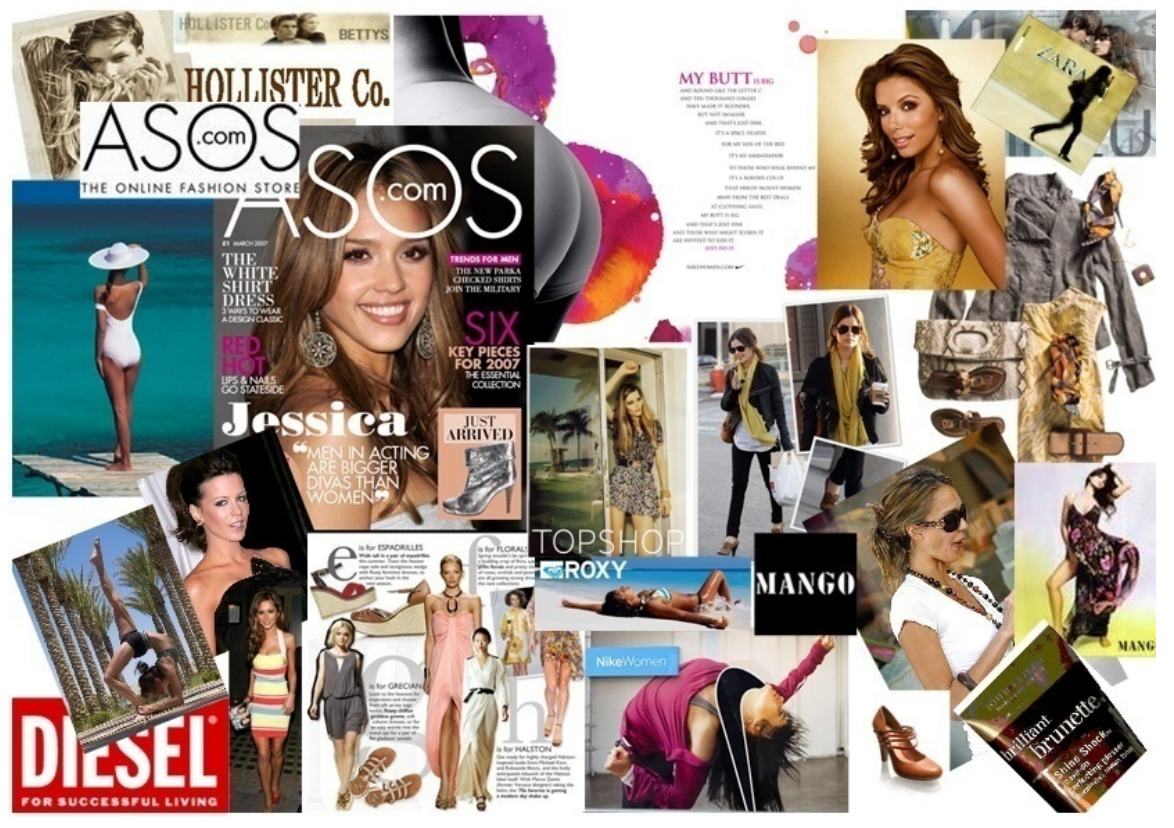

Note: Lyndsey's Collage including products and brands and illustrating a portfolio of celebrities and a range of consumer-celebrity relationships e.g. Compartmentalized, Aspirational and Best Friendship (Cheryl Cole, Kate Beckinsale, Eva Longoria, Jessica Alba and Rachel Bilson).

Figure 3: Collage example 2

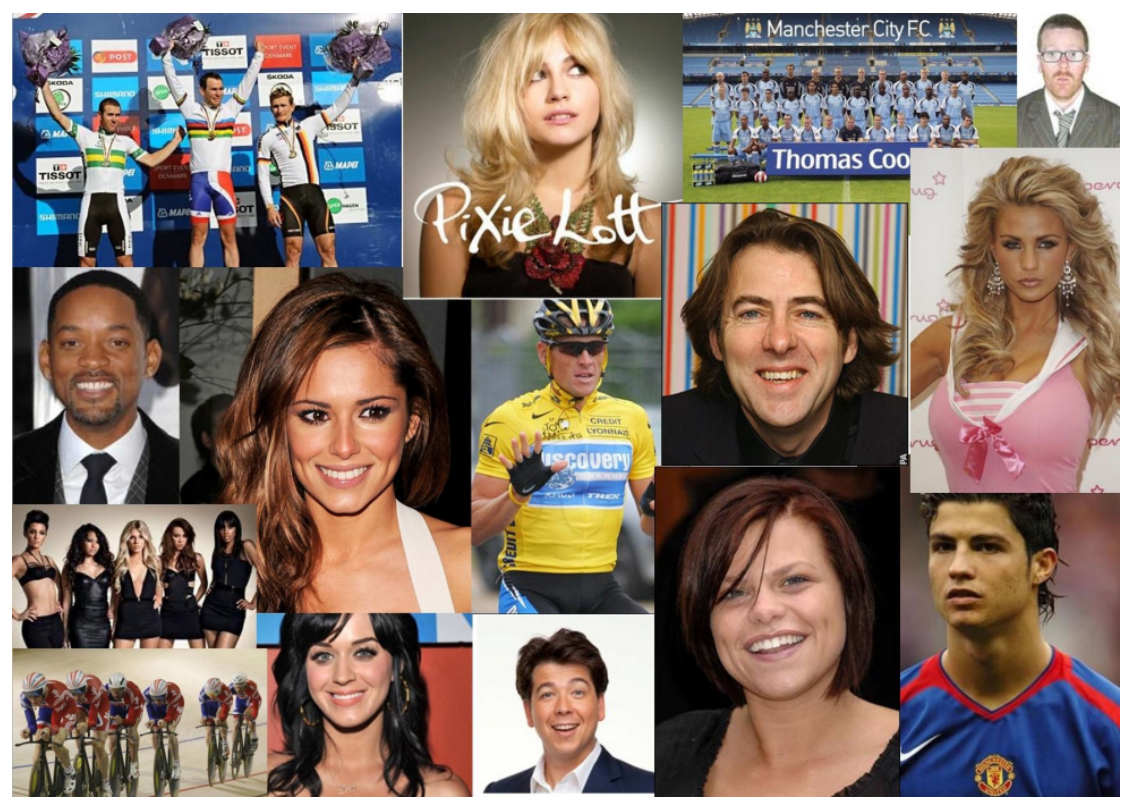

Note: Ethan's Collage illustrating a portfolio of celebrities and the full range of consumer-celebrity relationships e.g. Romantic (Pixie Lott, Katy Perry), Admiration (British Cyclist Mark Cavendish), Antagonistic (Katie Price and Christiano Ronaldo), Childhood Friendships (Will Smith) etc.

Interview data was transcribed verbatim and analysis was both deductive and inductive.

Some key themes emerged from existing literature whereas others emerged from the data 
itself. The analysis involved an iterative, part to whole, strategy. An understanding of each individual participant's story was developed, in addition to noting the commonalities across interviews (Thompson, Locander, \& Pollio, 1989; Thompson, \& Haytko, 1997). A hermeneutic process, whereby 'text and researcher are engaged in a cycle of re-interpretation and substantiation' (Hackley, 2003, p. 11) was adopted. Earlier readings (literature) and initial analysis shaped later analysis, and allowed the researchers 'to recognize and explore patterns not noted in the initial analysis' (Thompson \& Haytko, 1997, p. 20). Throughout this hermeneutic process, literature was consulted to aid in the development of interpretations.

\section{Findings}

We first present our framework: Consumer-celebrity relationships and links with congruency and marketing practice (Figure 4). This framework emerged from the data analysis yet is presented upfront to inform the structure of findings. The framework illustrates a range of relevant consumer-celebrity relationships and each relationship form is linked with an aspect of (possible) self and congruency. Examples from marketing practice illustrate the potential uses to marketers of engaging with, or encouraging, different consumer-celebrity relationships. Romantic-led relationships are excluded from our analysis. These romanticallymotivated relationships have been discussed elsewhere (Wohlfeil \& Whelan, 2012) and are worthy of much greater discussion than space allows. Space also restricts the number of participant examples we elaborate per relationship form. However, we include more extracts in the framework (Figure 4) in order to illustrate a fuller range of examples. 